\title{
Effect of Temperatures on the Embryonic Development, Morphometrics and Survival of Macrobrachium Idella Idella (Hilgendorf, 1898)
}

\section{Soundarapandian P*, Dinakaran GK and Varadharajan D}

Centre of Advanced Study in Marine Biology, Faculty of Marine Sciences, Annamalai University, Parangipettai-608 502, Tamil Nadu, India

\begin{abstract}
The development of $M$. idella idella eggs incubated at four different temperatures $\left(26,30,33\right.$ and $\left.36^{\circ} \mathrm{C}\right)$. An increase in major axis length was evident at $26,30,33$ and $36^{\circ} \mathrm{C}$. However at $36^{\circ} \mathrm{C}$, size variation increased with developmental stages, indicating abnormalities until $192 \mathrm{~h}$, after which total mortality was observed. A distinct change in morphometric parameters (major half axis, minor half axis, area and perimeter) was demonstrated at higher temperatures, irrespective of the developmental duration of eggs. Length of hatched embryos increased with increasing incubation temperatures. Therefore a rapid rate of increase of major half axis and early hatching was observed at $33^{\circ} \mathrm{C}$. The larva hatched first in $33^{\circ} \mathrm{C}(241 \mathrm{hrs})$ then followed by $30^{\circ} \mathrm{C}(265 \mathrm{hrs})$ and $26^{\circ} \mathrm{C}(302 \mathrm{hrs})$. In $36^{\circ} \mathrm{C}(182 \mathrm{~h})$ there was total mortality during embryonic development so there was no hatching.
\end{abstract}

Keywords: M. idella Idella; Embryonic development; Temperatures; Effect; Survival

\section{Introduction}

The emission of greenhouse gases and carbon dioxide are expected to increase global mean temperature by $1.5-4.5^{\circ} \mathrm{C}$ over the next halfcentury [1]. The impact of such a large temperature will affect the biological functions of freshwater and marine fishes and shellfishes, as most of the species are poikilothermic in nature. Thermal tolerance of aquatic animals is also dependent on acclimation temperature and the duration of acclimation [2]. Over the years, attention has focused on the thermal tolerance of embryos and larvae [3] that are more sensitive to temperature changes than adult fishes [4]. The earlier investigation on Labeo rohita revealed similar results [5]. The embryos of temperate species are more sensitive to extreme temperatures than embryos of tropical species [6]. In general, thermal limits are narrower for early stages and reduced survival of embryos and juveniles. Whereas it was wider for adults [7]. It is also reported that upper lethal temperatures of embryos, larvae [8] and adults [9] of the freshwater Mozambique tilapia (Oreochromis mossambica) varies in the range of $2^{\circ} \mathrm{C}$ among different life stages. In $M$. rosenbergii and $P$. serratus higher temperature seems to be shortening the incubation period [10]. Hence, the present study was undertaken to assess the effect of low and higher temperatures on the incubation period and embryonic development of edible prawn $M$. idella idella.

\section{Materials and Methods}

\section{Experimental animals}

Gravid or Berried females $(80-90 \mathrm{~mm})$ with opaque, greenish, round or oval in shape fertilized eggs in their brood pouch were used for the present experiment.

\section{Experimental conditions}

Twelve newly spawned brooders were stocked; one in each 120L fiber glass tank to assess the effect of incubation temperature on embryonic stages of $M$. idella idella Acclimation was carried out at one degree per day from water temperature $\left(25^{\circ} \mathrm{C}\right)$. Since the experiment was carried out during December to January the normal water temperature was found to be $25-26^{\circ} \mathrm{C}$.

\section{Temperature maintenance}

The test temperatures $\left(26,30,33\right.$ and $\left.36^{\circ} \mathrm{C}\right)$ were regulated by using automatic thermostat until hatching of the eggs. Sampling of eggs was carried out once the cleavage was completed, since this early development phase was not easily observed and was considered as the initial period $(0 \mathrm{~h})$. Eggs were sampled aseptically by gently removing a bunch of eggs from the brood pouch using sterilized forceps and separated with the help of needle and forceps without damaging the eggs. After each sampling, brooders were given a 1-min prophylactic fungus dip treatment in malachite green $\left(5 \mathrm{mg} \mathrm{L}^{-1}\right)$ before being returned to incubation tanks.

\section{Sampling}

In four different temperatures the embryonic stages of two brooders were rarely matched. Therefore, embryos were sampled at several intervals (i.e. 0, 24, 48, 72, 96, 120, 144, 168, 192, 216, 240, 264, 288 and $312 \mathrm{~h}$ ) from each brooder. Organogenesis, developmental changes and physiological processes were recorded under a light microscope. Eggs collected from four sampling points of brood pouch (anterior to posterior) were pooled to minimize sampling error due to position of eggs in brood pouch and assessed the percentage mortality of fully developed embryos (from an aggregate of 12 embryos/brooder) at the onset of hatching. Embryo dimensions (major axis, minor axis, area and perimeter) were measured at 48 -h intervals $(0,48,96,144,192 \mathrm{~h})$ until total mortality or hatching occurred.

\section{Results}

\section{Organogenesis and morphophysiology of eggs}

Development of $M$. idella idella eggs incubated at four different

*Corresponding author: Soundarapandian P, Centre of Advanced Study in Marine Biology, Faculty of Marine Sciences, Annamalai University, Parangipettai -608 502, Tamil Nadu, India, Tel: 04144-243223; E-mail: soundsuma@gmail.com

Received August 14, 2014; Accepted October 29, 2014; Published November 03, 2014

Citation: Soundarapandian P, Dinakaran GK, Varadharajan D (2014) Effect of Temperatures on the Embryonic Development, Morphometrics and Survival of Macrobrachium Idella Idella (Hilgendorf, 1898). J Aquac Res Development 5: 280 doi:10.4172/2155-9546.1000280

Copyright: (C) 2014 Soundarapandian P, et al. This is an open-access article distributed under the terms of the Creative Commons Attribution License, which permits unrestricted use, distribution, and reproduction in any medium, provided the original author and source are credited. 
Citation: Soundarapandian P, Dinakaran GK, Varadharajan D (2014) Effect of Temperatures on the Embryonic Development, Morphometrics and Survival of Macrobrachium Idella Idella (Hilgendorf, 1898). J Aquac Res Development 5: 280. doi:10.4172/2155-9546.1000280

Page 2 of 6

temperatures is presented in Plate 1 . At $0 \mathrm{~h}$, eggs in all the treatments were in similar phase of development (morula stage) and primodial mesodermal and endodermal cells were visible. After $24 \mathrm{~h}$, the blastocyst was visible in all the four-temperature treatments. Embryos were visible after $48 \mathrm{~h}$ in all the treatments. However, abnormal embryonic development was evident at $36^{\circ} \mathrm{C}$. At $72 \mathrm{~h}$, the primodial compound eye was visible. At $96 \mathrm{~h}$, a considerable increase in the length of the major axis was seen at higher temperatures $(30,33$ and $\left.36^{\circ} \mathrm{C}\right)$. At $120 \mathrm{~h}$, star shaped and round protoplasmic islands was visible at 33 and $36^{\circ} \mathrm{C}$, respectively and heartbeat was discernible at all temperature treatments. The compound eye with a visible optic lobe was visible at higher temperatures $\left(30,33\right.$ and $\left.36^{\circ} \mathrm{C}\right)$. At $144 \mathrm{~h}$, star shaped protoplasmic islands appeared at lower temperatures (26 and $30^{\circ} \mathrm{C}$ ). Rudiments of appendages started developing at all acclimation temperatures. At $168 \mathrm{~h}$, paired compound eyes were visible in all treatments. At $192 \mathrm{~h}$, star shaped protoplasmic islands were seen at lower temperatures $\left(26\right.$ and $\left.30^{\circ} \mathrm{C}\right)$ while at $36^{\circ} \mathrm{C}$, protoplasmic islands appeared was degenerated. After $192 \mathrm{~h}$, complete mortality was noticed at $36^{\circ} \mathrm{C}$ (Plate 1 ).

At lower temperatures, rudiments of appendages were visible. The primodial digestive canal developed in segments as a dotted line in the posterior region, and appeared to originate from primodial hepatopancreas. The primodial brain was visible at the anterior part of primodial hepatopancreas. The major half axis attained maximum length at the time of hatching. Hatching was initiated by a sudden twitching movement in the posterior region (below the compound eye) by means of the rudimentary antennule. At the time of hatching, telson (or tail) and rudiments of uropod (folded below compound eye) unfolded and the embryonic case was removed from anterior portion by straightening of abdominal segments. Embryos hatched out with a jerky movement and all the anterior appendages in the cephalothoracic region (including walking legs) were started moving vigorously. The larva hatched first in $33^{\circ} \mathrm{C}(241 \mathrm{hrs})$ then followed by $30^{\circ} \mathrm{C}(292 \mathrm{hrs})$ and $26^{\circ} \mathrm{C}(340 \mathrm{hrs})$. In $36^{\circ} \mathrm{C}(192 \mathrm{~h})$ there was total mortality during embryonic development so there was no hatching. Finally, larvae appeared bilaterally symmetrical (zoea 1) (Tables 1-3 and Figure 1). The embryonic development duration decreased with increasing temperatures as indicated by the negative slope in the linear regression equation, $y=14.909 x+732.15$ and $R 2=0.9932$ (Figure 2).

\section{Embryonic morphometry}

The data on embryonic morphometry of $M$. idella idella exposed to four incubation temperatures $\left(26,30,33\right.$ and $\left.36^{\circ} \mathrm{C}\right)$ are reported in Table 1. An increase in major axis length was evident at 26, 30, 33 and

\begin{tabular}{|c|c|c|}
\hline S. No. & Incubation temperatures $\left({ }^{\circ} \mathbf{C}\right)$ & Mortality at hatching (\%) \\
\hline 1 & 26 & $28.75 \pm 0.70$ \\
\hline 2 & 30 & $25.0 \pm 0.77$ \\
\hline 3 & 33 & $42.33 \pm 0.66$ \\
\hline 4 & 36 & $99.00 \pm 0.49$ \\
\hline
\end{tabular}

Table 1: Percentage mortality of fully developed embryos at different incubation temperatures (mean of 12 values $\pm \mathrm{SE}$ )

\begin{tabular}{|c|c|c|}
\hline S.No. & Incubation temperatures $\left({ }^{\circ} \mathbf{C}\right)$ & Duration of development \\
\hline 1 & 26 & $340.00 \pm 0.81$ \\
\hline 2 & 30 & $292.08 \pm 0.79$ \\
\hline 3 & 33 & $241.00 \pm 0.95$ \\
\hline 4 & 36 & $182.07 \pm 0.53$ \\
\hline
\end{tabular}

Table 2: Duration of embryonic development with increasing incubation temperatures from morula to eggs hatching (mean of 12 values \pm SE).

\begin{tabular}{|c|c|c|c|c|c|}
\hline \multirow[t]{2}{*}{ Parameter } & \multirow{2}{*}{\begin{tabular}{|c|}
$\begin{array}{c}\text { Duration of } \\
\text { embryonic } \\
\text { development }\end{array}$ \\
(h) \\
\end{tabular}} & \multicolumn{4}{|c|}{ Acclimation temperatures $\left({ }^{\circ} \mathrm{C}\right)$} \\
\hline & & 26 & 30 & 33 & 36 \\
\hline \multirow{6}{*}{$\begin{array}{l}\text { Major half } \\
\text { axis }(\mu \mathrm{m})\end{array}$} & 0 & $260.15 \pm 3.54$ & $270.3 \pm 3.33$ & $275.71 \pm 2.63$ & $275.06 \pm 3.21$ \\
\hline & 48 & $273.26 \pm 2.96$ & $276.65 \pm 2.64$ & $279.17 \pm 1.36$ & $281.61 \pm 2.36$ \\
\hline & 96 & $279.18 \pm 3.08$ & $285.95 \pm 1.86$ & $291.11 \pm 3.23$ & $289.23 \pm 2.15$ \\
\hline & 144 & $287.23 \pm 2.67$ & $290.60 \pm 4.38$ & $298.20 \pm 2.21$ & $303.10 \pm 3.25$ \\
\hline & 192 & $293.12 \pm 3.56$ & $303.72 \pm 3.25$ & $308.16 \pm 2.06$ & $311.69 \pm 7.31$ \\
\hline & Mean \pm SE & $278.58 \pm 5.72$ & $285.44 \pm 5.77$ & $290.47 \pm 5.99$ & $292.13 \pm 6.75$ \\
\hline \multirow{6}{*}{$\begin{array}{l}\text { Minor half } \\
\text { axis }(\mu \mathrm{m})\end{array}$} & 0 & $224.61 \pm 3.18$ & $233.07 \pm 4.37$ & $234.06 \pm 1.62$ & $235.16 \pm 3.02$ \\
\hline & 48 & $227.15 \pm 2.96$ & $233.5 \pm 2.38$ & $235.61 \pm 1.68$ & $232.22 \pm 2.12$ \\
\hline & 96 & $231.38 \pm 2.24$ & $235.61 \pm 2.52$ & $237.56 \pm 3.18$ & $234.81 \pm 4.16$ \\
\hline & 144 & $234.77 \pm 2.52$ & $236.04 \pm 1.86$ & $238.11 \pm 2.20$ & $239.16 \pm 3.69$ \\
\hline & 192 & $236.03 \pm 2.37$ & $237.30 \pm 2.45$ & $238.65 \pm 1.85$ & $240.56 \pm 3.28$ \\
\hline & Mean \pm SE & $230.79 \pm 2.17$ & $235.10 \pm 0.79$ & $236.80 \pm 0.85$ & $236.38 \pm 1.52$ \\
\hline \multirow{6}{*}{$\begin{array}{l}\text { Area }\left(x 10^{5}\right) \\
\left(\mu \mathrm{m}^{2}\right)\end{array}$} & 0 & $1.83 \pm 0.38$ & $1.98 \pm 0.28$ & $2.03 \pm 0.23$ & $2.03 \pm 0.36$ \\
\hline & 48 & $1.95 \pm 0.56$ & $2.03 \pm 0.18$ & $2.07 \pm 0.32$ & $2.05 \pm 0.26$ \\
\hline & 96 & $2.03 \pm 0.28$ & $2.12 \pm 0.42$ & $2.18 \pm 0.19$ & $2.13 \pm 0.19$ \\
\hline & 144 & $2.12 \pm 0.26$ & $2.16 \pm 0.33$ & $2.23 \pm 0.16$ & $2.28 \pm 0.42$ \\
\hline & 192 & $2.17 \pm 0.41$ & $2.26 \pm 0.27$ & $2.31 \pm 0.40$ & $2.35 \pm 0.32$ \\
\hline & Mean \pm SE & $2.02 \pm 0.07$ & $2.11 \pm 0.06$ & $2.16 \pm 0.06$ & $2.17 \pm 0.08$ \\
\hline \multirow{6}{*}{$\begin{array}{l}\text { Perimeter } \\
(\mu \mathrm{m})\end{array}$} & 0 & $1522.16 \pm 24.36$ & $1580.60 \pm 32.21$ & $1600.68 \pm 30.12$ & $1602.09 \pm 26.62$ \\
\hline & 48 & $1571.32 \pm 32.41$ & $1601.86 \pm 28.06$ & $1616.41 \pm 22.02$ & $1613.44 \pm 17.24$ \\
\hline & 96 & $1603.19 \pm 30.21$ & $1637.73 \pm 31.68$ & $1660.04 \pm 19.83$ & $1645.47 \pm 42.33$ \\
\hline & 144 & $1639.06 \pm 28.25$ & $1653.67 \pm 22.63$ & $1684.04 \pm 34.22$ & $1702.71 \pm 36.23$ \\
\hline & 192 & $1661.53 \pm 22.32$ & $1698.82 \pm 33.72$ & $1717.01 \pm 28.43$ & $1734.07 \pm 23.54$ \\
\hline & Mean \pm SE & $1599.45 \pm 22.5$ & $1634.54 \pm 18.8$ & $1655.64 \pm 19.5$ & $1659.56 \pm 24.6$ \\
\hline
\end{tabular}

Table 3: Effect of incubation temperatures $\left(26,30,33,36^{\circ} \mathrm{C}\right)$ on morphological changes during the embryonic development of $M$. idella idella eggs until hatching.

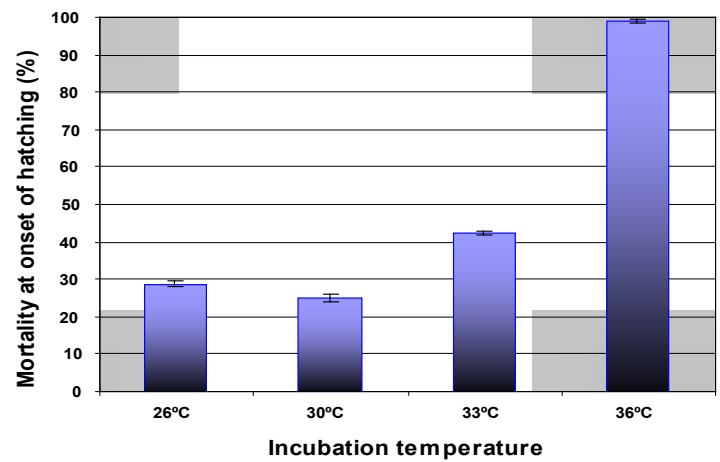

Figure 1: Percentage mortality of fully developed embryos at the onset of hatching.

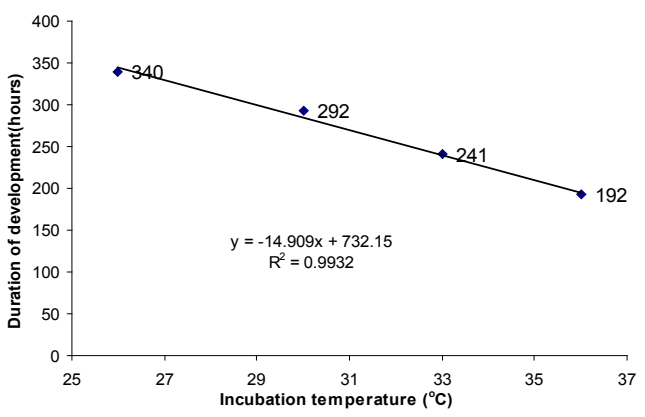

Figure 2: Duration of embryonic development with increasing incubation temperatures (morula to hatching). Data labels against each incubation temperature indicate the actual duration of development (mean of 12 values). 
Citation: Soundarapandian P, Dinakaran GK, Varadharajan D (2014) Effect of Temperatures on the Embryonic Development, Morphometrics and Survival of Macrobrachium Idella Idella (Hilgendorf, 1898). J Aquac Res Development 5: 280. doi:10.4172/2155-9546.1000280

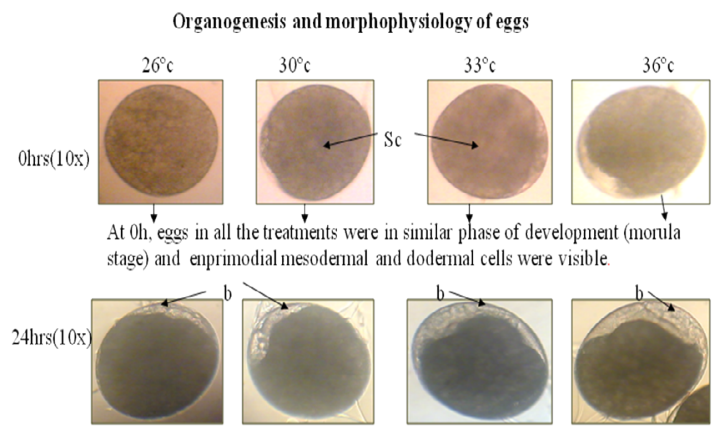

After 24 h, the blastocyst was visible in all the four-temperature treatments

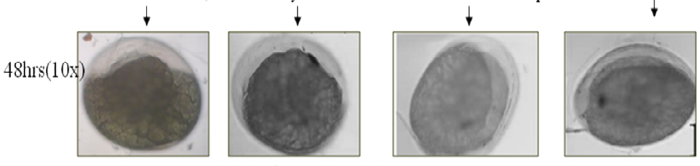

Embryos were visible after $48 \mathrm{~h}$ in all the treatments. However, abnormal enbryonic development was evident at $36^{\circ} \mathrm{C}$

$26^{\circ} \mathrm{C}$

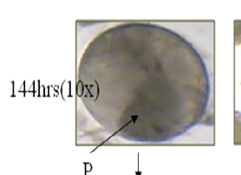

$\mathrm{P} \downarrow$

At 144h star shaped potoplasmic islands appeared at lower temperatures $(26$ and $30^{\circ} \mathrm{C}$ ). Rudiments of appendages statted developing at all acclimation temperatures.

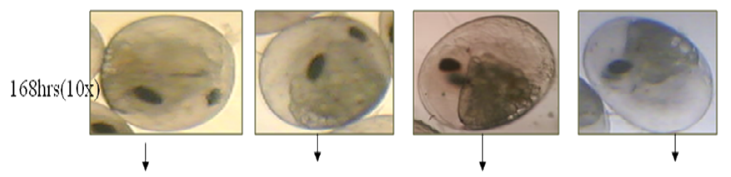

At $168 \mathrm{~h}$, paired compound eyes were visible in all treatments

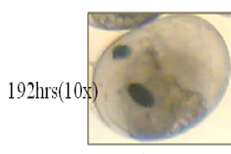

$\downarrow$

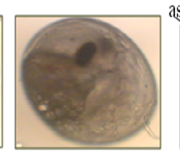

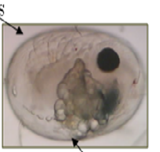

$\downarrow \mathrm{T}$

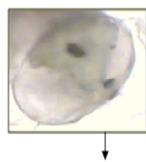

At $192 \mathrm{~h}$, star shaped protoplasmic islands were seen at lower temperatures $\left(26\right.$ and $\left.30^{\circ} \mathrm{C}\right)$ while at $36^{\circ} \mathrm{C}$, protoplasmic islands appeared was degenerated. After $192 \mathrm{~h}$, complete mortality was noticed at $36^{\circ} \mathrm{C}$ $26^{\circ} \mathrm{C}$

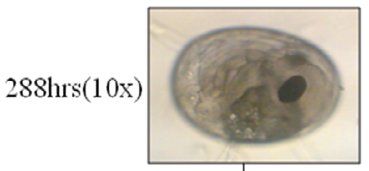

om

312

$30^{\circ} \mathrm{C}$

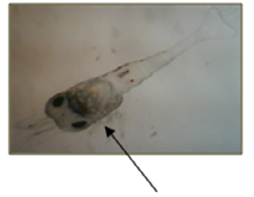

Hatched larval at

292hrs, 4x $\downarrow$

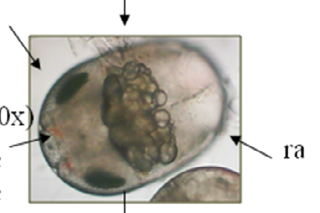

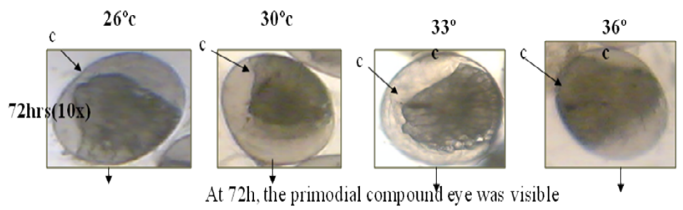
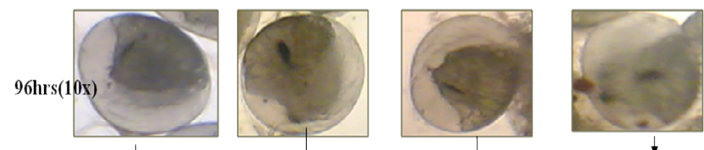

At $96 \mathrm{~h}$, a considerable increase in the length of the major axis was seen at higher temperatures $\quad\left(30,33\right.$ and $\left.36^{\circ} \mathrm{C}\right)$.
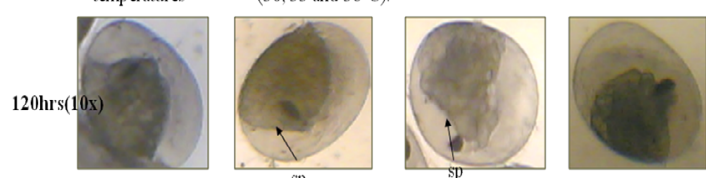

At $120 \mathrm{~h}$, star shaped and round protoplasmic islands was visible at 33 and $36^{\circ} \mathrm{C}$, respectively and heartheat was discernible at all temperature treatments. The compound eye with a visible optic lobe was visible at higher temperatures $\left(30,33\right.$ and $\left.36^{\circ} \mathrm{C}\right)$
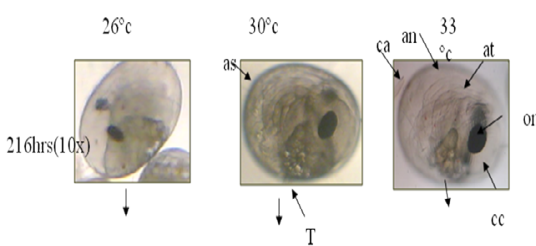

om
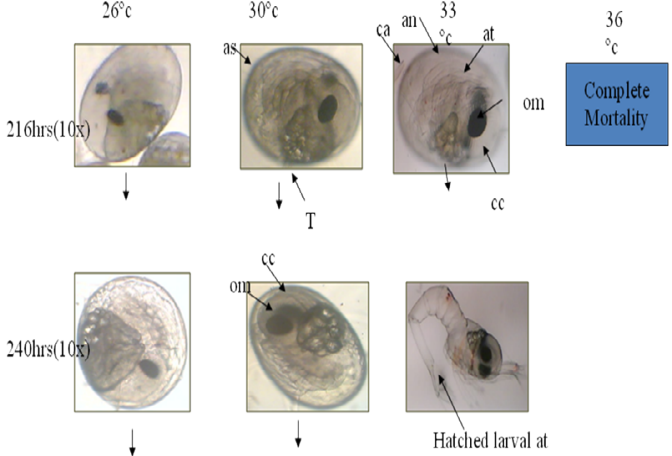

Hatched larval at
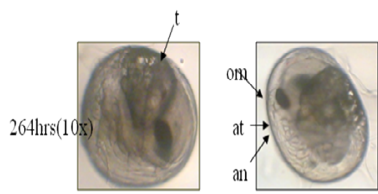

$241 \mathrm{hrs}, 4 \mathrm{x}$

(AS) abdominal segment.

(T) transisucent globules

(CA) cephalotharacic appendages,

(An) antennulae

(At) antannae,

(Omi) Ommatidia

(CC)Cephalothoracic carapace

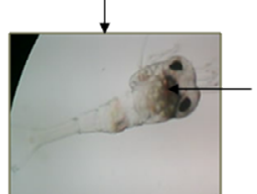

Hatched larva at

340 hrs, $4 \mathrm{x}$

Plate 1: Development of $M$. idella idella eggs incubation at four different temperatures. sc-superfical cleavage, b-blastocyst, c-compound eye, p-protoplasmic island, sp-starshaped protoplasmic island, ra-rudimentary alimentary canal, an-antennule, at-antannae, om-Ommatidia, cc-Cephalothoracic carapace, caephalotharacic appendages, as-abdominal segment. 
$36^{\circ} \mathrm{C}$. However at $36^{\circ} \mathrm{C}$, size variation increased with developmental stages, indicating abnormalities until $192 \mathrm{~h}$, after which total mortality was observed. A distinct change in morphometric parameters (major half axis, minor half axis, area and perimeter) was demonstrated at higher temperatures, irrespective of the developmental duration of eggs. Length of hatched embryos increased with increasing incubation temperatures.

Therefore a rapid rate of increase of major half axis and early hatching was observed at $33^{\circ} \mathrm{C}$ (Plate 1$)$.

\section{Discussion}

Prior knowledge on the effects of temperature on cultured aquatic organisms, especially during embryogenesis, is a prerequisite for successful hatchery operation and seed production. Embryonic development is a complex process in which cellular differentiation and proliferation occurs simultaneously but at different rates [11]. Both organogenesis and somatic growth are controlled by enzymatic activities. Embryonic development of ectotherms mainly depends on the differential expression of certain genes and temperature [12] and the rates of their biological functions are critically dependent on environmental temperature. The effect of temperature on developmental rate is direct and development is faster at higher temperatures. However, this increase of developmental rate of embryos at higher temperatures occurs only within tolerable thermal limits [13]. In the present study, organogenesis and physiological responses of $M$. idella idella eggs incubated at different temperatures indicates that higher temperatures increase the rate of embryonic development. Dark brownish structures appearing on the surface of embryos during the development phase of $M$. idella idella are known as protoplasmic islands. Morphology of protoplasmic islands of embryos was specific at different incubation temperatures. Embryos with round, oval or star shaped protoplasmic islands demonstrated normal development until hatching. But at $36^{\circ} \mathrm{C}$ the protoplasmic island were not clearly visible. Immediately after appearance of degenerated protoplasmic islands, complete mortality was recorded at $36^{\circ} \mathrm{C}$. Further isolation and structural analysis of these protoplasmic islands may indicate a functional significance during early development of $M$. idella $M$. idella idella. It is evident that heat shock proteins are induced at early developmental phases in response to various physiological stimuli (growth factors, cell differentiation, and hormonal stimulation) and under the influence of temperature [14]. In M. rosenbergii also at $36^{\circ} \mathrm{C}$ complete mortality of embryos was reported once the protoplasmic island was degenerated [15].

Morphometric measurements indicated that an early increase in the length of the major axis of embryos at higher temperatures. Finally, length at hatching was increased with increasing temperatures and the larval major axis was highest at $33^{\circ} \mathrm{C}$. However, complete mortality was observed at $36^{\circ} \mathrm{C}$ after 10 days, which indicates that incubation at $36^{\circ} \mathrm{C}$ is an upper temperature threshold for M. idella idella embryos. Earlier reports on duration of hatching in Macrobrachium spp at different temperatures indicates that eggs hatch out in 25 days at $26^{\circ} \mathrm{C}, 20$ days at $28-28.5^{\circ} \mathrm{C}$ and in 17 days at $32^{\circ} \mathrm{C}$ [16]. In the present study, in $M$. idella idella hatching took first at $33^{\circ} \mathrm{C}(241 \mathrm{hrs})$ than followed by $30^{\circ} \mathrm{C}(292 \mathrm{hrs})$ and $26^{\circ} \mathrm{C}(340 \mathrm{hrs})$. Even though hatching took first at $33^{\circ} \mathrm{C}$ the survival rate was low when compared with 30 and $26^{\circ} \mathrm{C}$. In $M$. rosenbergii the survival was more at $33^{\circ} \mathrm{C}$ than in 29 and $25^{\circ} \mathrm{C}$ [15]. In most crustaceans the incubation period is highly dependent on the temperature $[17,18]$. Incubation periods of Moreton Bay (Australia) population of S. serrata are usually in early spring, at water temperatures of $18-20^{\circ} \mathrm{C}$ [17]. Water temperatures in estuaries and coastal waters along the north coast of South Africa range between $17-22^{\circ} \mathrm{C}$ in winter and $23-30^{\circ} \mathrm{C}$ in summer [19]. Temperature directly influences the developmental rate and development is faster at increasing temperatures. However, this increase of developmental rate of embryos with increase in temperatures occurs only within the acceptable thermal limits $[7,13]$. In general, thermal limits are narrower for early stages and reduced survival of embryos and juveniles but wider for the adults [7]. Acclimation temperature or thermal history may also affect the temperature tolerance of embryos. In crayfish, time needed for egg development varies with temperature, suggesting the possibility of extending or reducing the incubation period [20]. In crustacean eggs, metabolic rate increases with temperature [21], which affects growth [22], survival [23], and yolk absorption rates [24]. However, high temperature could cause high mortality or serious deformities during egg incubation [25]. Studies on fish [26,27], crustaceans [23,25] and molluscs [28] have shown that there are different approaches to studying the effects of temperature on development. One of the criteria is to measure changes in lipid, protein, and carbohydrate biochemical contents during egg development, which reflect utilization rate [29].

Experiments with Liocarcinus depurator showed that a three-fold decrease in development time could occur in successive batches of eggs incubated during the early spring to mid-summer breeding season in one locality [30]. In L. holsatus and Necora puber hatching success was greater at low temperature-low salinity and high temperaturehigh salinity combinations. However, L. holsatus was relatively more tolerant to the lower range while $N$. puber was more tolerant to the higher range [31]. The better survival of $L$. holsatus eggs and larvae at lower temperatures than that of $N$. puber may reflect field situation; $L$. holsatus produces eggs and larvae earlier and at colder temperatures than does $N$. puber $[30,32]$ noted that within a related group of species there was a direct relationship between egg size and incubation period. In the present study the eggs of the same species (M. idella idella) responded differently when exposed to same environmental conditions [33] studied the effect of temperature on egg extrusion rate in C. quadricarinatus. They found that egg production was more frequent when mature females were maintained in water over $28^{\circ} \mathrm{C}$ compared to $25^{\circ} \mathrm{C}$ and lower. In general the survival and incubation time decreased with increased temperature [34]. As expected, higher temperature caused faster development because it had a direct effect on physiological and biochemical processes [35]. This is a reflection of higher metabolic rate [20] and a decrease in the duration of embryonic or larval development, commonly documented for crustaceans [23]. This effect was previously observed in C. quadricarinatus by $[34,36]$ reported approximately 28 days for egg incubation until hatching at $28^{\circ} \mathrm{C}$, which is very similar to the present work. The difference in water temperature from 22 to $31^{\circ} \mathrm{C}$ resulted in $50 \%$ shorter development time from egg extrusion to juvenile stage in the work. However, shorter development time in response to higher water temperature is compromised with abnormal development and lower survival [37] found most hatchling crayfish reared at extremely high temperatures had deformed limbs and failed to moult normally. In the present study, deformities and abnormal sizes were not considered, although some deformed hatchlings were observed at $33^{\circ} \mathrm{C}$ that subsequently died. Crustaceans are highly sensitive to environmental changes during ontogeny, and are therefore at higher risk to reach lethal temperature during this period $[24,38]$ report that the consumption rate of total lipid and protein in Artemia gradually increases as temperature increases. The higher lipid depletion rate at higher temperature occurs because lipids are the main source of energy during ontogeny of aquatic 
Citation: Soundarapandian P, Dinakaran GK, Varadharajan D (2014) Effect of Temperatures on the Embryonic Development, Morphometrics and Survival of Macrobrachium Idella Idella (Hilgendorf, 1898). J Aquac Res Development 5: 280. doi:10.4172/2155-9546.1000280

Page 5 of 6

organisms $[39,40]$. Growth and differentiation processes demand large amounts of energy and all metabolic processes are intensified when the temperature is higher [25]. It was also observed that lipid consumption per day intensified at hatching, which could be related to a higher energy production need during this process [41]. For proteins, the consumption rate during embryogenesis might increase as temperature rises [42]. At high temperatures, tissue synthesis is inefficient due to the high cell proliferation rate, and more protein is used as fuel [39]. In the present study, embryonic development was assessed after acclimating the brooders (carrying newly released eggs in the brood chamber) at the rate of $1^{\circ} \mathrm{C}$ per day to test the temperatures and maintained until hatching, as described by [43]. A negative slope in the linear regression of development time to hatching, indicates a strong inverse relation with incubation temperature.

Our study indicates a direct linear relationship between development rates of $M$. idella idella embryos with incubation temperature. Hence, a direct relation between organogenesis and morphological measurements and development was established. A rapid increase in major axis length observed at 30 and $33^{\circ} \mathrm{C}$ with a concomitant rate of development and earlier hatching. But when compared to $30^{\circ} \mathrm{C}$ with $33^{\circ} \mathrm{C}$ the survival rate is very low. Increase in larval length was observed at higher incubation temperatures indicate that such larvae may develop into dominant prawns. Therefore, incubation temperature may prove vital in producing healthy, high quality prawn seeds for successful prawn farming, by taking advantage of "leap frog pattern" of enhanced growth and overall production. However, this hypothesis needs to be investigated by rearing freshwater prawns from embryos until adult stages at higher temperatures.

In the present study the optimal temperature for incubating $M$. idella idella eggs is recorded at $30^{\circ} \mathrm{C}$ considering the rate of development and hatching percentage. Total mortality was found at $36^{\circ} \mathrm{C}$. High temperatures are related to poor cementing and attachment of eggs [31]. In the case of $M$. rosenbergii, the development and hatching percentage were maximum at $33^{\circ} \mathrm{C}$ than in $29^{\circ} \mathrm{C}$ and $99 \%$ mortality was recorded at $36^{\circ} \mathrm{C}$ [15]. Poor hatching percentage and formation of malformed embryos in later stages at $36^{\circ} \mathrm{C}$ suggest that this rearing temperature is well above the tolerance limit for development of L. rohita eggs or may be due to the lack of adequate enzymes involved in hatching [44]. This may be due to adaptive response of M. idella idella embryos evolved over the years due to global warming and climatic changes. The complete mortality percentage and gross morphological abnormalities at $36^{\circ} \mathrm{C}$ suggest that the thermal limit for embryonic development of M. idella idella is below $36^{\circ} \mathrm{C}$. However, some of the embryos reared at $33^{\circ} \mathrm{C}$ reached relatively advanced developmental stages in a short time, inspite of low survival rate and gross abnormalities.

From the point of fertilization until hatching, low temperatures retard and high temperatures accelerate embryonic development [45,46]. According to [26] $29-33^{\circ} \mathrm{C}$ is acceptable for M. rosenbergii embryonic development, which is higher than earlier reports of 29$31^{\circ} \mathrm{C}$ [47]. According to [5] the optimal temperature for incubating $L$. rohita eggs is recorded at $31^{\circ} \mathrm{C}$ considering the rate of development and hatching percentage, which is higher than earlier reports of $L$. rohita [48]. But in the present experiment, M. idella idella at $26-30^{\circ} \mathrm{C}$ were found to be optimum temperature than other experimental temperature. Overall results suggest that $30^{\circ} \mathrm{C}$ is the ideal temperature for egg incubation of $M$. idella idella for faster embryonic development, better hatching percentage and least time duration for attaining given ontogenic stages. In $L$. rohita at 26 and $31^{\circ} \mathrm{C}$ suggests that these temperature ranges are most suitable for incubation but $31^{\circ} \mathrm{C}$ is the ideal temperature for egg incubation. A rise in the optimum temperature for embryonic development over the years may be due to continuous warming in the test region along with a gain of adaptive capability and induced thermal tolerance over the years. This hypothesis needs to be tested at the genetic level. These results may be a prelude to effectively utilize the benefits of temperature on better hatching rate and reduced hatchery man-days and ultimately the cost of production in $M$. idella idella hatcheries. However, hatchery seed production of $M$. idella idella is recommended between 26 and $30^{\circ} \mathrm{C}$. This study reveals that M. idella idella embryos can accommodate climatic changes due to global warming up to $33^{\circ} \mathrm{C}$, without hampering the reproduction and embryonic development.

\section{Acknowledgment}

Authors are grateful to the Director of the Centre and the authorities of Annamalai University for providing with facilities. They extend their thanks to Prof L. Kannan, for critically going through the manuscript and offering comments. The Umino Pet Palace, Chennai is acknowledged for the supply of fishes. We also thankfully acknowledge the valuable comments obtained from three anonymous reviewers, which greatly improved the manuscript.

\section{References}

1. Hounghton RA, Woodwell GM (1989) Global climatic change. Sci American 260: 36-44.

2. Chatterjee N, Pal AK, Manush SM, Das T, Mukherjee SC (2004) Thermal tolerance and metabolic status of Labeo rohita and Cyprinus carpio early fingerlings acclimated to three different temperatures. J Ther Biol 29: 265-270.

3. Houde ED (1989) Comparative growth, mortality, and energetics of marine fish larvae: temperature and implied latitudinal effects. Fish Bull US 87: 471-495.

4. Brett JR (1969) Temperature and fishes. Chesapeake Science 10: 275-276.

5. Das T, Pal AK, Chakraborty SK, Manush SM, Dalvi RS, et al. (2006) Thermal dependence of embryonic development and hatching ratein Labeo rohita, Hamilton, 1822. Aquacult 255: 536-541.

6. Buddington RK, Hazel JR, Poroshov SI, Vaneehenhaam J (1993) Ontogeny of the capacity for homeoviscous adaptation in white sturgeon (Acipenser transmontanus). J Exp Zool 256: 18-28.

7. Cossins AR, Bowler K (1987) Temperature Biology of Animals. Chapman and Hall, London.

8. Subasinghe RP, Sommerville C (1992) Effects of temperature on hatchability development and growth of eggs and yolk-sac fry of Orechromis mossambicus (Peters) under artificial incubation. Aqua Fisher Manag 23: 31-90.

9. Allanson BR, Noble RG (1964) The tolerance of Tilapia mossambica (Peters) to high temperature. Trans Amer Fish Soc 93: 323-332.

10. Manush SM, Pal AK, Chatterjee N, Das T, Mukherjee SC (2004) Therma tolerance and oxygen consumption of Macrobrachium rosenbergii acclimated to three temperatures. J Ther Biol 29: 15-19.

11. Hall BK (1922) Evolutionary Developmental Biology. Chapman and Hall, London.

12. Ojanguren AF, Brana F (2003) Thermal dependence of embryonic growth and development in brown trout. J Fish Biol 62: 580-590.

13. Atkinson D (1996) Ectotherm life-history responses to developmental temperature.

14. Gething M, Sambrook J (1992) Protein folding in the cell. Nat 355: 35-45.

15. Manush SM, Pal AK, Das T, Mukherjee SC (2006) The influence of temperatures ranging from 25 to $36^{\circ} \mathrm{C}$ on developmental rates, morphometrics and survival of freshwater prawn (Macrobrachium rosenbergii) embryos. Aquacult 256: 529536

16. Ogasawara YF (1984) Ecology of prawns and shrimp.

17. Haesman MP, Fielder DE (1983) Laboratory spawning and mass rearing of the mangrove crab Scylla serrata (Forskal), from first zoea to first crab stage. Aquacult 34: 303-316.

18. Hines $\mathrm{AH}$ (1986) Larval pattern in the life histories of Brachyuran crabs 
Citation: Soundarapandian P, Dinakaran GK, Varadharajan D (2014) Effect of Temperatures on the Embryonic Development, Morphometrics and Survival of Macrobrachium Idella Idella (Hilgendorf, 1898). J Aquac Res Development 5: 280. doi:10.4172/2155-9546.1000280

Page 6 of 6

(Crustacea, Decapoda, Brachyura). Bull Mar Sci 39: 444-466.

19. Robertson WD, Kruger A (1994) Size at maturity, mating and spawning in the portunid crab, Scylla serrata (Forskal) in Natal, South Africa. Est Coast Shelf Sci 39: 185-200.

20. Reynolds J (2002) Growth and reproduction.

21. Naylor K, Taylor E, Bennett D (1999) Oxygen uptake of developing eggs of Cancer pagurus (Crustacea: Decapoda: Cancridae) and consequent behavior of ovigerous females. J Mar Biol Ass 79: 305-315.

22. Jones DA (1994) Effect of temperature on growth and survival of the tropical freshwater crayfish Cherax quadricarinatus (Von Martens) Decapoda: Parastacidae.

23. Paula J, Mendes R, Paci S, Mc Laughin P, Gheradi F, et al. (2001) Combined effects of temperature and salinity on the larval development of the estuarine mud prawn Upogebia africana (Crustacea, Thalassinidae). Hydrobiol 449: 141 148.

24. Evjemo O, Danielsen T, Olsen $Y$ (2001) Losses of lipid, protein and n-3 fatty acids in enriched Artemia franciscana starved at different temperatures. Aquacult 193: 65-80.

25. Kumlu M, Eroldogan O, Aktas M (2000) Effects of temperature and salinity on larval growth, survival and development of Penaeus semisulcatus. Aquacult 188: $167-173$.

26. Ojanguren A, Reyes-Gavilan F, Rodrıguez R (1999) Effects of temperature on growth and efficiency of yolk utilization in eggs and pre-feeding larval stages of Atlantic salmon. Aquacult Int 7: 81-87

27. Keckeis H, Kamler E, Bauer-Nemeschkal E, Schneeweiss K (2001) Survival, development and food energy partitioning of nase larvae and early juveniles at different temperatures. J Fish Biol 59: 45-61.

28. Gilroy A, Edwards S (1998) Optimum temperature for growth of Australian abalone Haliotis rubra (Leach) and greenlip abalone, Haliotis laevigata (Leach). Aquacult Int 29: 481-485.

29. Lemos D, Phan V (2001) Energy partitioning into growth, respiration, excretion and exuvia during larval development of the shrimp Farfantepenaeus paulensis. Aquacult 199: 131-143.

30. Wear RG (1974) Incubation in British decapod crustacea, and the effects of temperature on the rate and success of embryonic development. J Mar Bio Assoc 54: 745-762.

31. Choy SC (1986) Ecological studies on Liocarcinus puber (L.) and L. holsatus (Fabricius) (Crustacea, Brachyura, Portunidae) around the Gower Peninsula, South Wales.

32. Choy SC (1988) Reproductive biology of Liocarcinus puber and L. holsatus (Decapoda, Brachyura, Portunidae) from the Gower Peninsula, South Wales. Mar Ecol 9: 227-241.

33. Yeh H, Rouse D (1995) Effects of water temperature, density, and sex ratio on the spawning rate of red claw crayfish Cherax quadricarinatus (Von Martens). $J$ World Aquacult Soc 26: 160-164

34. Zhao Y, Meng F, Chen L, GU Z, Xu G, et al. (2000) Effects of different gradien temperatures on embryonic development of the Cherax quadricarinatus (Crustacea, Decapoda). J Lake Sci 12: 59-62.

35. Brown C, Terwilliger N (1999) Developmental changes in oxygen uptake in Cancer magister (Dana) in response to changes in salinity and temperature. Exp Mar Biol Ecol 241

179-192.

36. Yeh $\mathrm{H}$, Rouse $\mathrm{D}$ (1994) Indoor spawning and egg development of the red claw crayfish Cherax quadricarinatus. J World Aquacult Soc 25: 297-301.

37. Rhodes C (1981) Artificial incubation of the eggs of the crayfish Austropotamobius pallipes. Aquacult 25: 129-150.

38. Agard J (1999) A four dimensional response surface analysis of the ontogeny of physiological adaptation to salinity and temperature in larvae of the palaemonid shrimp Macrobrachium rosenbergii (de Man). J Exp Mar Biol Ecol 236: 209233.

39. Anderson DT (1982) Embryology. Acadamic Press, New York.

40. Holland DL (1978) Lipid reserves and energy metabolism in the larvae of benthic marine invertebrates.

41. Heras H, Gonzales-Baro M, Pollero R (2000) Lipid and fatty acid composition and energy partitioning during the embryo development in the shrimp Macrobrachium borellii. Lipids 35: 645-651.

42. Conceicao L, Ozorio R, Suurd E, Verreth J (1998) Amino acid profile and amino acid utilization in larval African catfish Clarias gariepinus, effects of ontogeny and temperature. Fish Physiol Biochem 19: 43-57.

43. Beitinger TL, Bennett WA, McCauley RW (2000) Temperature tolerances of North American freshwater fishes exposed to dynamic changes in temperature. Environ Biol Fishes 58: 237-275.

44. Reddy PK, Lam TJ (1991) Effect of thyroid hormones on hatching in the tilapia Oreochromis mossambicus. Gene Compar Endocri 81: 484-491.

45. Hart PR, Purser GJ (1995) Effects of salinity and temperature on eggs and larvae of the greenback flounder. Aquacult 136: 221-230.

46. Hamel P, Mangan P, East P, Lapointe M, Laurendeau P (1997) Comparison of different models to predict the in situ embryonic development rate of fish with special reference to white sucker (Catostomus commersoni). Canadian J Fish Aquat Sci 54: 190-197.

47. Sebastian CD (1996) A manual on seed production and farming of giant freshwater prawn, Macrobrachium rosenbegii. The Marine products Export Development Authority, (Ministry of Commerce, Govt of India), Pananmpilly Avenue, Cochin.

48. Ponnuraj M, Murugesan AG, Sukumaran N (2002) Effect of temperature on incubation time, fertilization rate and survival of the spawn of Rohu, Labeo rohita. 